\title{
Understanding the Quality Chasm for Hypertension Control in Diabetes: A Structured Review of "Co-maneuvers" Used in Clinical Trials
}

\author{
Aanand D. Naik, MD, Tim T. Issac, MD, Richard L. Street, Jr, PhD, and
}

Mark E. Kunik, MD, MPH

Background: Observational studies routinely describe a significant gap between rates of blood pressure control in routine diabetes care compared with those achieved in randomized controlled trials (RCTs).

Methods: We performed a systematic review of the literature to identify co-maneuvers used in RCTs, defined as ancillary activities or agents administered before, during, or immediately after the main agent under investigation (ie, principal maneuver), but not effectively translated to routine diabetes care. We searched multiple databases for RCTs evaluating the efficacy of treatments for hypertension control in adults with type 2 diabetes mellitus. We considered only phase III human studies of interventions that achieved blood pressure control and scrutinized all elements related to the implementation of the principal maneuver in each candidate study. These elements were then sorted into a taxonomy of co-maneuvers.

Results: Nearly all eligible RCTs used highly consistent groups of co-maneuvers. These typically began with (1) the use of consensual and clearly stated blood pressure goals; (2) frequent visits in which blood pressure levels were measured and compared with predefined goals; and, if the goal was not attained, (3) modifications to the treatment based on a detailed action plan that included communication of adverse events. Patient education, feedback to clinicians, and interventions for medication adherence were not commonly used among eligible trials.

Conclusions: Clinicians should translate key behavioral co-maneuvers along with clinically proven treatments for hypertension control in diabetes. These co-maneuvers are conceptually similar to collaborative goal setting and action planning interventions used in innovative chronic care programs. (J Am Board Fam Med 2007;20:469-478.)

Cardiovascular disease is the major cause of mortality among patients with type 2 diabetes, ${ }^{1}$ and uncon-

This article was externally peer reviewed.

Submitted 26 January 2007; revised 17 April 2007; accepted 23 April 2007.

From the Houston Center for Quality of Care and Utilization Studies (ADN, TTI, RLS, MEK) and South Central Mental Illness Research, Education, and Clinical Center (MEK), Michael E. DeBakey Veterans Affairs Medical Center, Houston, TX; Sections of Health Services Research (ADN, TTI, RLS, MEK), Geriatrics (ADN), and Diabetes and Endocrinology (ADN), Baylor College of Medicine, Houston, TX; Menninger Department of Psychiatry, Baylor College of Medicine, Houston, TX (MEK); and the Department of Communication, Texas A\&M University, College Station (RLS).

Funding: This article is the result of work supported with resources and the use of facilities at the Houston Center for Quality of Care and Utilization Studies, Michael E. DeBakey Veterans Affairs Medical Center. Dr. Naik is supported by an National Institutes of Health K23 grant (5K23AG027144-02) and a Hartford Geriatric Health Outcomes award.

Conflict of interest: none declared.

Corresponding author: Aanand D. Naik, MD, Houston Center for Quality of Care and Utilization Studies, Michael E. DeBakey Veterans Affairs Medical Center (152), 2002 Holcombe Blvd, Houston, TX 77030 (E-mail: anaik@bcm.tmc.edu). trolled hypertension is the primary risk factor for the macrovascular complications of diabetes. ${ }^{2}$ Fortunately, clinicians have numerous efficacious and costeffective treatments available for patients with diabetes and uncontrolled hypertension. ${ }^{2-4}$ Observational studies, however, routinely describe a significant gap between the rates of blood pressure control in routine diabetes care compared with those achieved in clinical trials. ${ }^{3,5,6}$ Rates of hypertension control vary from $30 \%{ }^{6,7}$ to $53 \%^{8}$ when a standard of $<140 / 90 \mathrm{~mm} \mathrm{Hg}$ is considered; however, these percentages fall precipitously ( $10 \%$ to $29 \%$ ) when more clinically efficacious standards are applied. ${ }^{6,8}$

There are many potential reasons for the high rate of uncontrolled hypertension in routine diabetes care. Poor access to regular medical care and affordable health insurance, ${ }^{9}$ poor adherence to medication because of troublesome side effects, ${ }^{10}$ the complexity of treatment regimens for multiple diabetes comorbidities, ${ }^{11}$ and clinician-related factors that contribute to therapeutic inertia. ${ }^{12-14}$ 
Clinical trials avoid many of the potential obstacles that create the substantive quality chasm ${ }^{15}$ between routine diabetes care and clinical trials. The quality chasm exists even among diabetics who have regular medical care and access to the same antihypertensive treatments used in clinical trials. , $^{5,13}$ The principal maneuvers of randomized controlled trials (RCTs), defined as the main agent responsible for the observed distinction between treatment and control groups, ${ }^{16}$ are typically translated to routine diabetes care. The quality chasm may be explained by the failure to translate other important characteristics of clinical trials that facilitate execution of the principal maneuver, especially those focused on clinician-patient communication and treatment planning.

The current study is a systematic review of RCTs for hypertension control in patients with type 2 diabetes mellitus meant to determine whether RCTs use a consistent set of co-maneuvers not often found in the routine care of hypertension control for type 2 diabetes. Co-maneuvers include ancillary activities or agents (eg, enhanced patient education, clinician decision support, timely follow-up, etc) that are administered before, during, or immediately after a principal maneuver is conducted and may have an additive or reinforcing effect. ${ }^{16}$ Many of these may be intuitive, but they have not often been systematically described in studies of hypertension control in diabetes or organized within a coherent conceptual framework.

\section{Methods}

\section{Data Sources and Screening Procedure}

We performed systematic MEDLINE, CINAHL, PsycINFO, and Cochrane Library searches of English language literature from 1986 to August 2005 using the search terms "hypertension" (prevention and control or therapy) or "antihypertensive agents" (therapeutic use) combined with "exp diabetes mellitus" (prevention and control or therapy). This initial search resulted in 2646 articles. A secondary filter using the search limits of "exp randomized controlled trials" or "controlled clinical trial" (publication type); "humans"; and "English language" resulted in 387 potentially relevant articles. In addition, we hand-searched publications reporting study designs and preliminary results from relevant trials and the reference lists of pertinent articles, including reviews and commentaries.

\section{Study Selection}

Two investigators (ADN and TTI) reviewed the abstracts or full articles (when the abstract was not sufficiently clear) of all 387 articles for inclusion and exclusion criteria. In reviewing abstracts, investigators included only publications that were RCTs and evaluated the clinical impact of efficacious treatments for hypertension in adults with type 2 diabetes mellitus. Only studies that measured blood pressure changes as a primary outcome or as a major process-of-care measure for a primary clinical outcome (eg, cardiovascular mortality, death from all causes, major macrovascular outcomes, and advanced microvascular outcomes) were included. In addition, the principal maneuver of the study, defined as the main agent responsible for the observed distinction between treatment and control groups ${ }^{16}$ was either a medication or a behavior-change therapy.

Among the 387 abstracts reviewed, we excluded studies that were not RCTs $(\mathrm{n}=113)$ and those involving adults under age 30 or with type 1 diabetes mellitus $(n=31)$, given that hypertension and diabetes in these populations are physiologically distinct from the more common comorbid diabetes and hypertension found among older adults with type 2 diabetes. In addition, studies with physiologic outcomes other than hypertension control $(\mathrm{n}=59)$, phase I or phase II trials of new therapies $(\mathrm{n}=27)$, studies currently in progress $(\mathrm{n}=9)$, and duplicate publications of the study (eg, secondary analyses) $(n=102)$ were excluded. Studies that failed to demonstrate efficacy for hypertension control were excluded to eliminate ineffective maneuvers as they relate to hypertension control (see below). This second-tier review yielded 55 articles reporting results from 41 primary studies. All 41 studies were independently reviewed by 2 or 3 reviewers, and disagreements were resolved by consensus using the methods described below. An additional 21 studies were removed during consensus meetings because, after more rigorous review, they were found to have one or more exclusion criteria. These studies were eliminated because they were nonrandomized or phase II trials $(\mathrm{n}=6)$, or they did not demonstrate significant reductions in hypertension $(\mathrm{n}=15)$. Among this latter group, we excluded 12 studies with the primary outcome of hypertension control that found no significant differences between intervention and control; the other 3 studies found no significant changes in 
blood pressure levels, despite significant improvements in the primary outcome (eg, diabetic nephropathy). Conversely, the remaining 20 studies include some studies in which no significant difference in hypertension control existed between intervention and comparison groups; however, both groups demonstrated significant blood pressure declines from baseline.

\section{Data Extraction}

Investigators independently analyzed each study using content analysis, ${ }^{17}$ with the explicit purpose of identifying principal and co-maneuvers used in these RCTs. Content analysis is an analytic process that was adapted to improve the rigor of the current structured review, and we implemented the process as follows. ${ }^{17}$ Investigators independently scrutinized all methodological elements (ie, co-maneuvers) administered before, during, and immediately after the principal maneuver in each candidate study to identify and sort these elements into distinct categories. The list of categories was then used to create a coding scheme for sorting and categorizing individual co-maneuvers. After reviewing an initial 10 studies, investigators convened to review the coding scheme and resolve discrepancies. Independently, investigators subsequently applied the revised coding scheme to each additional article. With the review of successive articles, the coding scheme was expanded, refined, and applied to previously reviewed articles. The final products of the independent and consensual analyses include the taxonomy of co-maneuvers, a listing of which co-maneuvers were used in each clinical trial, and a description of the characteristics comprising each co-maneuver. In addition, we extracted data on study design, participant eligibility criteria, procedures for recruitment of study participants, and the primary and secondary endpoints. These aspects of the reviewed studies are presented in the results because they could have some bearing on the results of the clinical trials.

\section{Results}

\section{Characteristics of Included Trials}

Important characteristics of the 20 trials included in our final analysis are outlined in Table 1 . The principal maneuver in studies 1 through 14 in Table 1 consisted of a specific medication compared with one or more established medications (ie, usual care). Another 5 studies $^{33-37}$ compared intensive management strategies of tight blood pressure monitoring and control to less aggressive management strategies. One additional study ${ }^{38}$ used patient-activation strategies as a principal maneuver, compared with conventional management. Given our eligibility criteria, most studies enrolled middle-aged or older patients with mild-to-moderate hypertension. All 20 studies used informed consent procedures to enroll patients, and all but one targeted recruits by reviewing patient charts or databases. Five studies ${ }^{29-31,37,38}$ (11 to 13 and 19 to 20 in Table 1) targeted physician practices to facilitate recruitment of eligible participants. In all studies, vascular morbidity or mortality was the primary outcome.

\section{Taxonomy of Co-maneuvers}

Seven different co-maneuvers were identified and clustered into 3 groups. The co-maneuvers include (1) frequency of follow-up clinic visits and (2) activities occurring at each visit; (3) instruction or feedback given to study clinicians and (4) health education offered to study participants; and (5) specificity and type of blood pressure target(s), (6) action plans for using and modifying study treatments, and (7) communication regarding adverse events resulting from the principal maneuvers. Table 2 describes the specific characteristics for each of the co-maneuvers, catalogued by study number. The taxonomy of co-maneuvers in Table 2 is oriented from most intensive to least intensive, with the most intensive characteristic on the left side of each row.

\section{Frequency of and Activities Performed at Clinic Visits}

In all but one study, ${ }^{38}$ there were frequent visits for the first 3 months (ie, baseline period) occurring on a weekly to monthly basis, followed by regular visits at least every 6 months. Studies with less frequent baseline visits tended to have visits every 3 to 4 months over the subsequent years. In addition to scheduling frequent visits, most studies used dedicated study coordinators or nurses who facilitated recruitment and retention of participants to follow-up visits. In every case, blood pressure levels were measured at every visit and compared with the blood pressure target. Except for the one study, ${ }^{38}$ RCTs used explicit action plans for initiating and modifying treatment until blood pressure targets 


\begin{tabular}{|c|c|c|c|c|c|c|}
\hline Clinical Trial & $\begin{array}{l}\text { Principal } \\
\text { Maneuver }\end{array}$ & $\begin{array}{l}\text { Comparison } \\
\text { Maneuver }\end{array}$ & $\begin{array}{l}\text { Study } \\
\text { Design }\end{array}$ & $\begin{array}{l}\text { Eligibility } \\
\text { Criteria }\end{array}$ & $\begin{array}{l}\text { Enrollment } \\
\text { Procedures }\end{array}$ & $\begin{array}{l}\text { Primary } \\
\text { Outcome }\end{array}$ \\
\hline $\begin{array}{l}\text { 1. SHEP (Systolic } \\
\text { Hypertension in Elderly) } \\
\text { subgroup }^{18}\end{array}$ & Chlorthalidone & $\begin{array}{l}\text { Placebo }+ \\
\text { Usual Care }\end{array}$ & $\mathrm{DB}$ & $\begin{array}{l}\text { Age } \geq 60 \text { years } \\
\text { NIDDM, BP } \\
\geq 160 / 90\end{array}$ & $\mathrm{IC}, \mathrm{RC}$ & Stroke \\
\hline $\begin{array}{l}\text { 2. SYST-EUR (Systolic } \\
\text { Hypertension in Europe } \\
\text { Trial) subgroup }{ }^{19}\end{array}$ & Nitrendipine & $\begin{array}{l}\text { Placebo }+ \\
\text { Usual Care }\end{array}$ & $\mathrm{DB}$ & $\begin{array}{l}\text { Age } \geq 60 \text { years } \\
\text { SBP } \geq 160, \\
\text { controlled DM }\end{array}$ & $\mathrm{IC}, \mathrm{RC}$ & Stroke \\
\hline $\begin{array}{l}\text { 3. ALLHAT (Antihypertensive } \\
\text { and Lipid Lowering } \\
\text { Treatment to Prevent Heart } \\
\text { Attacks Trial) subgroup }{ }^{20,21}\end{array}$ & Chlorthalidone & $\begin{array}{l}\text { Lisinopril, } \\
\text { Amlodipine }\end{array}$ & $\mathrm{DB}$ & $\begin{array}{l}\text { Age } \geq 55 \text { years } \\
\text { DM, HTN + } \\
\text { CV RFs }\end{array}$ & $\mathrm{IC}, \mathrm{RC}$ & $\begin{array}{l}\text { Composite CV } \\
\text { endpoints }\end{array}$ \\
\hline $\begin{array}{l}\text { 4. CAPPP (Captopril } \\
\text { Prevention Project) } \\
\text { subgroup }^{22}\end{array}$ & Captopril & Usual Care & $\mathrm{O}-\mathrm{BE}$ & $\begin{array}{l}\text { Age } 25 \text { to } 65 \text { years, } \\
\text { DM }+ \text { DBP } \\
>100\end{array}$ & $\mathrm{IC}, \mathrm{RC}$ & $\begin{array}{l}\text { Composite CV } \\
\text { endpoints }\end{array}$ \\
\hline $\begin{array}{l}\text { 5. LIFE (Losartan Intervention } \\
\text { for Endpoint Reduction in } \\
\text { Hypertension Study) } \\
\text { subgroup }^{23}\end{array}$ & Losartan & Atenolol & $\mathrm{DB}$ & $\begin{array}{l}\text { Age } 55 \text { to } 80 \text { years, } \\
\text { DM, HTN + } \\
\text { LVH }\end{array}$ & $\mathrm{IC}, \mathrm{RC}$ & $\begin{array}{l}\text { Composite } \mathrm{CV} \\
\text { endpoints }\end{array}$ \\
\hline $\begin{array}{l}\text { 6. STOP-2 (Swedish Trial in } \\
\text { Old Patients with } \\
\text { Hypertension) subgroup }\end{array}$ & $\begin{array}{l}\text { Calcium antagonists, } \\
\text { ACE inhibitors }\end{array}$ & Usual Care & $\mathrm{O}-\mathrm{BE}$ & $\begin{array}{c}\text { Age } 70 \text { to } 84 \text { years, } \\
\text { DM }+ \text { HTN }\end{array}$ & IC, RC & $\begin{array}{l}\text { Composite CV } \\
\text { endpoints }\end{array}$ \\
\hline $\begin{array}{l}\text { 7. INSIGHT (International } \\
\text { Nifedipine GITS Study) } \\
\text { subgroup }^{25}\end{array}$ & Nifedipine GITS & Diuretics & $\mathrm{DB}$ & $\begin{array}{l}\text { Age } 55 \text { to } 80 \text { years, } \\
\text { DM, HTN }+ \\
\text { CV RFs }\end{array}$ & $\mathrm{IC}, \mathrm{RC}$ & $\begin{array}{l}\text { Composite CV } \\
\text { endpoints }\end{array}$ \\
\hline $\begin{array}{l}\text { 8. JMIC-B (Japan Multicenter } \\
\text { Investigation for } \\
\text { Cardiovascular Diseases) } \\
\text { subgroup }^{26}\end{array}$ & Nifedipine & ACE inhibitor & $\mathrm{O}-\mathrm{BE}$ & $\begin{array}{l}\text { Age } 55 \text { to } 75 \text { years, } \\
\text { DM, HTN }+ \\
\text { CAD }\end{array}$ & $\mathrm{IC}, \mathrm{RC}$ & $\begin{array}{l}\text { Composite CV } \\
\text { endpoints }\end{array}$ \\
\hline $\begin{array}{l}\text { 9. IDNT (Irbesartan Diabetic } \\
\text { Nephropathy Trial) }\end{array}$ & Irbesartan & $\begin{array}{l}\text { Amlodipine }+ \\
\text { usual care }\end{array}$ & $\mathrm{DB}$ & $\begin{array}{l}\text { Age } 30 \text { to } 70 \text { years, } \\
\text { DM, HTN + } \\
\text { albuminuria }\end{array}$ & $\mathrm{IC}, \mathrm{RC}$ & $\begin{array}{l}\text { Composite CV } \\
\text { endpoints }\end{array}$ \\
\hline $\begin{array}{l}\text { 10. CONVINCE (Controlled } \\
\text { Onset Verapamil } \\
\text { Investigation of } \\
\text { Cardiovascular Endpoints) } \\
\text { subgroup }^{28}\end{array}$ & Verapamil & Usual care & $\mathrm{DB}$ & $\begin{array}{l}\text { Age } \geq 55 \text { years, DM } \\
+ \text { HTN }\end{array}$ & $\mathrm{IC}, \mathrm{RC}$ & $\begin{array}{l}\text { Composite CV } \\
\text { endpoints }\end{array}$ \\
\hline $\begin{array}{l}\text { 11. BENEDICT (Bergamo } \\
\text { Nephrologic Diabetes } \\
\text { Complications Trial) }\end{array}$ & Trandolapril & $\begin{array}{l}\text { Verapamil }+ \\
\text { placebo }\end{array}$ & $\mathrm{DB}$ & $\begin{array}{l}\text { Age }>40 \text { years, } \\
\text { DM, HTN + no } \\
\text { micoalbuminuria }\end{array}$ & $\begin{array}{l}\mathrm{IC}, \mathrm{RC} \\
\mathrm{TPP}\end{array}$ & Microalbuminuria \\
\hline $\begin{array}{l}\text { 12. INVEST (International } \\
\text { Verapamil SR-trandolapril } \\
\text { Study) subgroup } \\
30\end{array}$ & Verapamil & Atenolol & $\mathrm{O}-\mathrm{BE}$ & $\begin{array}{l}\text { Age }>70 \text { years, } \\
\text { DM, HTN }+ \\
\text { CAD }\end{array}$ & $\begin{array}{l}\mathrm{IC}, \mathrm{RC} \\
\mathrm{TPP}\end{array}$ & $\begin{array}{l}\text { Composite CV } \\
\text { endpoints }\end{array}$ \\
\hline $\begin{array}{l}\text { 13. FACET (Fosinopril versus } \\
\text { Ampldipine Cardiovascular } \\
\text { Events Randomized Trial) } \\
\text { subgroup }^{31}\end{array}$ & Fosinopril & $\begin{array}{c}\text { Amlodipine }+ \\
\text { usual care }\end{array}$ & $\mathrm{O}-\mathrm{BE}$ & $\begin{array}{c}\text { Age }>60 \text { years, DM } \\
+\mathrm{BP} \geq 140 / 90\end{array}$ & $\begin{array}{l}\mathrm{IC}, \mathrm{RC} \\
\mathrm{TPP}\end{array}$ & $\begin{array}{l}\text { Composite CV } \\
\text { endpoints }\end{array}$ \\
\hline $\begin{array}{l}\text { 14. NORDIL (Nordic Diltiazam } \\
\text { Study) subgroup }\end{array}$ & Diltiazam & Usual care & $\mathrm{O}-\mathrm{BE}$ & $\begin{array}{l}\text { Age } 50 \text { to } 80 \text { years, } \\
\text { DM }+ \text { DBP } \\
>100\end{array}$ & $\mathrm{IC}, \mathrm{RC}$ & $\begin{array}{l}\text { Composite CV } \\
\text { endpoints }\end{array}$ \\
\hline $\begin{array}{l}\text { 15. Hypertension in Diabetes } \\
\text { Study } \mathrm{IV}^{33}\end{array}$ & Tight BP control & $\begin{array}{l}\text { Less tight BP } \\
\text { control }\end{array}$ & $\mathrm{OP}$ & $\begin{array}{l}\text { Age } 25 \text { to } 65 \text { years, } \\
\text { DM, BP } \geq 150 / \\
85\end{array}$ & $\mathrm{IC}, \mathrm{RC}$ & $\begin{array}{l}\text { Macro/Micro Vascular } \\
\text { Complications }\end{array}$ \\
\hline $\begin{array}{l}\text { 16. UKPDS (United Kingdom } \\
\text { Prospective Diabetes Study) } \\
\text { subgroup }^{34}\end{array}$ & Tight BP control & $\begin{array}{l}\text { Less tight BP } \\
\text { control }\end{array}$ & $\mathrm{OP}$ & $\begin{array}{c}\text { Age } 25 \text { to } 65 \text { years, } \\
\text { DM }+ \text { HTN }\end{array}$ & IC, RC & Death \\
\hline $\begin{array}{l}\text { 17. HOT (Hypertension } \\
\text { Optimal Treatment Study) } \\
\text { subgroup }^{35}\end{array}$ & Tight BP control & $\begin{array}{l}\text { Less tight } \mathrm{BP} \\
\text { control }\end{array}$ & $\mathrm{O}-\mathrm{BE}$ & $\begin{array}{l}\text { Age } 50 \text { to } 80 \text { years, } \\
\mathrm{DM}+\mathrm{DBP}> \\
100\end{array}$ & $\mathrm{IC}, \mathrm{RC}$ & $\begin{array}{l}\text { Composite CV } \\
\text { endpoints }\end{array}$ \\
\hline $\begin{array}{l}\text { 18. ABCD (Appropriate Blood } \\
\text { Pressure Control in } \\
\text { Diabetes Trial) }\end{array}$ & Tight BP control & $\begin{array}{l}\text { Less tight BP } \\
\text { control }\end{array}$ & $\mathrm{OP}$ & $\begin{array}{l}\text { Age } 40 \text { to } 75 \text { years, } \\
\text { DM + untreated } \\
\text { DBP }>80\end{array}$ & IC, RC & Diabetic nephropathy \\
\hline 19. Steno-2 Study ${ }^{37}$ & $\begin{array}{l}\text { Intensive multi-risk } \\
\text { factor control }\end{array}$ & $\begin{array}{l}\text { Conventional } \\
\text { strategies }\end{array}$ & $\mathrm{OP}$ & $\begin{array}{l}\mathrm{DM}+ \\
\quad \text { microalbuminuria }\end{array}$ & $\begin{array}{l}\mathrm{IC}, \mathrm{RC} \\
\mathrm{TPP}\end{array}$ & $\begin{array}{l}\text { Macro- or } \\
\text { microvascular } \\
\text { complications }\end{array}$ \\
\hline $\begin{array}{l}\text { 20. High Risk Patients with } \\
\text { Diabetes: A Motivation and } \\
\text { Teaching Intervention }\end{array}$ & $\begin{array}{l}\text { Personalized BP } \\
\quad \text { goals }\end{array}$ & Usual care & $\mathrm{OP}$ & $\begin{array}{l}\text { Age } 45 \text { to } 70 \text { years, } \\
\text { DM }+\mathrm{BP}> \\
140 / 90\end{array}$ & $\begin{array}{l}\mathrm{IC}, \mathrm{RC} \\
\mathrm{TPP}\end{array}$ & $\begin{array}{l}\text { Microvascular } \\
\text { complications }\end{array}$ \\
\hline
\end{tabular}

ACE, angiotensin-converting enzyme; BP, blood pressure; DB, double blinded; O-BE, open, blinded to endpoints; OP, open pragmatic; DM, diabetes mellitus; HTN, hypertension; SBP, systolic blood pressure; DBP, diastolic blood pressure; CV, cardiovascular; RF, risk factors; IC, informed consent; RC, reviewed medical charts; TPP, targeted physician practices. 
Table 2. Co-Maneuvers Used in Randomized Controlled Trials

\begin{tabular}{|c|c|c|c|c|}
\hline \multirow{2}{*}{$\frac{\text { Co-maneuver Types }}{\text { Frequency of clinic visits }}$} & \multicolumn{4}{|c|}{ Co-maneuver Characteristics by Study (Indicated by Reference Number) } \\
\hline & $\begin{array}{l}\text { Frequent baseline visits: } \\
18,22-31,35,36,38\end{array}$ & $\begin{array}{l}\text { Every } 3 \text { to } 4 \text { months: } \\
18-20,25,27,29,33, \\
34,37\end{array}$ & $\begin{array}{l}\text { Every } 6 \text { months: } 22-24, \\
26,28,30-32,35,36\end{array}$ & $\begin{array}{l}\text { Annual follow-up } \\
\text { only: } 38\end{array}$ \\
\hline $\begin{array}{l}\text { Activities occurring at each } \\
\text { visit }\end{array}$ & $\begin{array}{l}\text { Treatment titrated unless } \\
\text { BP at target: } 18-37\end{array}$ & $\begin{array}{l}\text { BP measured and } \\
\text { compared to target: } \\
18-38\end{array}$ & $\begin{array}{l}\text { Assessment of study } \\
\text { endpoints: } 18-38\end{array}$ & \\
\hline $\begin{array}{l}\text { Feedback given to study } \\
\text { clinicians }\end{array}$ & $\begin{array}{r}\text { Detailed feedback and } \\
\text { decision support: } 38\end{array}$ & $\begin{array}{l}\text { Structured reminders of } \\
\text { participants' status: } \\
20,30,33,34\end{array}$ & $\begin{array}{l}\text { No additional structured } \\
\text { decision support: } 18 \\
19,22-28,32,35-37\end{array}$ & \\
\hline $\begin{array}{l}\text { Education offered to study } \\
\text { participants }\end{array}$ & $\begin{array}{l}\text { Counseling, support, and } \\
\text { behavior modification } \\
\text { education: } 37,38\end{array}$ & $\begin{array}{l}\text { Structured education at } \\
\text { follow-up visits: } 18 \\
21\end{array}$ & $\begin{array}{l}\text { No structured } \\
\text { education: } 19,22-36\end{array}$ & \\
\hline $\begin{array}{l}\text { Specificity of blood } \\
\text { pressure target(s) }\end{array}$ & $\begin{array}{l}\text { A specific systolic and/or } \\
\text { diastolic BP target: } 18 \text {, } \\
20-38\end{array}$ & $\begin{array}{l}\text { Targeted BP change } \\
\text { from baseline: } 19,25, \\
27,31\end{array}$ & & \\
\hline $\begin{array}{l}\text { Action plan for } \\
\text { modification of } \\
\text { treatments }\end{array}$ & $\begin{array}{l}\text { Action plan explicitly } \\
\text { defined: } 18-37\end{array}$ & $\begin{array}{l}\text { Specific medications or } \\
\text { medication classes: } \\
18-38\end{array}$ & & \\
\hline $\begin{array}{l}\text { Communication of adverse } \\
\text { events from principal } \\
\text { maneuver }\end{array}$ & $\begin{array}{l}\text { Adverse events discussed } \\
\text { at each follow-up: } \\
18-37\end{array}$ & $\begin{array}{l}\text { Specific adverse events } \\
\text { queried: } 19,20-27 \text {, } \\
29,30,32-37\end{array}$ & $\begin{array}{l}\text { No published } \\
\text { documentation of } \\
\text { adverse events: } 38\end{array}$ & \\
\hline
\end{tabular}

BP, blood pressure.

were attained. In many studies, the primary function of the frequent baseline visits was aggressive titration of treatments to achieve blood pressure targets. Targets were typically reached within the first 6 months of most studies.

\section{Education of and Feedback to Clinicians and Participants}

Most studies provided modest but targeted feedback to clinicians, and a few provided structured education for patient participants. Clinicians received only decision support regarding participants' blood pressure control status and titration schedules in over two thirds of the studies reviewed. Similarly, the studies that offered structured education to patients typically limited it to baseline visits. Only the Motivation and Teaching Intervention $^{38}$ (study 20 in Table 1) gave both detailed feedback and decision support to clinicians and structured counseling with behavior modification education to all participants. The Antihypertensive and Lipid Lowering Treatment to Prevent Heart Attack (ALLHAT) trial did provide both structured postrandomization education to study participants as well as structured reminders of participants' status to clinicians. Patient education regarding pharmacological and behavioral therapies occurred primarily at baseline visits with some nonstandardized education provided on an ongoing basis. Clinician education in ALLHAT included courses in hypertension decision support and reminders regarding the hypertension control status and outcomes of patient participants. ${ }^{20}$

\section{Blood Pressure Targets, Treatment Action Plans, and Communicating Adverse Events}

Every study in the current review used some form of blood pressure target. These targets consisted of specific blood pressure levels and/or a specific change in blood pressure from baseline that were made explicit to all participants at time of enrollment. Even though the primary outcomes in each of the included studies were typically clinical cardiovascular endpoints, the focus of discussion during clinician-patient interactions was attainment of the blood pressure target and progress with the treatment action plan. Nearly all studies mandated modification of treatments until blood pressure targets were reached or significant adverse events developed. Even among studies where the principal maneuver was not a specific medication, strict treatment action plans were present and offered minimal latitude to clinicians in terms of types and dosages of medications. No study offered clinicians complete discretion regarding the types and intensity of treatments that could be used to lower blood pressure. 


\section{Discussion}

The current review of hypertension control in diabetes mellitus reinforces the importance of the delivery of health services when attempting to translate innovations from clinical trials to routine practice. With only one partial exception, the clinical trials described in this review all used 3 core groups of co-maneuvers to maximize the effect of their principal maneuver. These co-maneuvers typically began with (1) the use of consensual and clearly stated blood pressure goals. At every visit, (2) blood pressure levels were measured and compared with predefined goals. If the goal was not attained, (3) modifications to the treatment were implemented based on a detailed action plan. Contrary to expectations, most studies gave little additional feedback or support to clinicians and participants' health education and counseling were often limited to information about target and current blood pressure levels and adverse events. In aggregate, participants represented a wide spectrum of ages, ethnicities, baseline blood pressures, diabetes progression, and vascular disease severity at enrollment.

The specific co-maneuvers identified as key elements of RCTs by this review are not surprising and, like the other facets of clinical trial enrollment (eg, enhanced access and low out-of-pocket costs for care), are intuitively designed to increase the likelihood of success for the principal maneuver. ${ }^{39}$ For example, clinical efficacy trials often use prerandomization screening to identify patient-level factors associated with improved short-term adherence to medication (ie, appropriate social support, assessment of motivation and self-efficacy with care, and screening for adverse events). ${ }^{40}$ The effectiveness of co-maneuvers to enhance long-term patient adherence to antihypertensive therapy, a far more important measure when translating clinical trial findings to routine care of chronic conditions, is less conclusive. ${ }^{41}$ Other interventions, such as clinical reminders, case management, nurse-assisted care, or patient education and support for hypertension control, were not frequently used by the 20 studies described in this review. Many studies using these interventions as maneuvers were excluded from the final analysis because they had nonsignificant differences or even negative outcomes compared with usual care. These studies did include some co-maneuvers but, in addition to not meeting the inclusion criteria, they did not use co-maneuvers from all 3 core groups described above. Furthermore, in a systematic review of 41 studies using clinical reminders, audit and feedback, or other "organizational" interventions as principal maneuvers for improving diabetes outcomes, no intervention produced significant improvements in hypertension control; however, some did improve glycemic or lipid control. ${ }^{42}$ Blood pressure self-monitoring and patient-centered counseling have demonstrated some efficacy as maneuvers for hypertension control, ${ }^{43}$ but these modalities have not been studied for hypertension control in diabetes.

\section{Hypertension Control in Routine Care}

The quality chasm in hypertension control cannot be attributed only to limitations in access to medical care or selective patient recruitment by clinical trials. Hyman and Pavlik ${ }^{44}$ found that not having a regular physician attributed only $8 \%$ of the population risk for patients in a national study with acknowledged but uncontrolled hypertension. Given that most patients undergoing treatment in their sample reported having health insurance and an average of 6 physician visits per year, Hyman and Pavlik concluded that "treated but uncontrolled hypertension occurs largely under the watchful eye of the health care system." ${ }^{24}$

\section{Health Communication and Bebavioral Determinants in Diabetes Care}

The phenomenon of treated but uncontrolled hypertension is often placed under the rubric of clinical inertia, and many of the co-manuevers described in this review address clinical inertia directly. Clinical inertia is typically blamed on physicians who are poorly trained, overestimate the quality of care provided, or use "soft" reasons for not intensifying care. ${ }^{13,14}$ In contrast, physicians are often compelled to change therapy based on specific requests by activated patients. ${ }^{45,46}$ Clinical inertia, therefore, may be more common among passive patients. For example, Oliveria et $\mathrm{al}^{47}$ found that many patients undergoing treatment for hypertension often did not know what their most recent blood pressure was and that nearly two thirds could not correctly give their blood pressure goal.

An additional theory suggests that patients who actively seek and adhere to treatment but are un- 


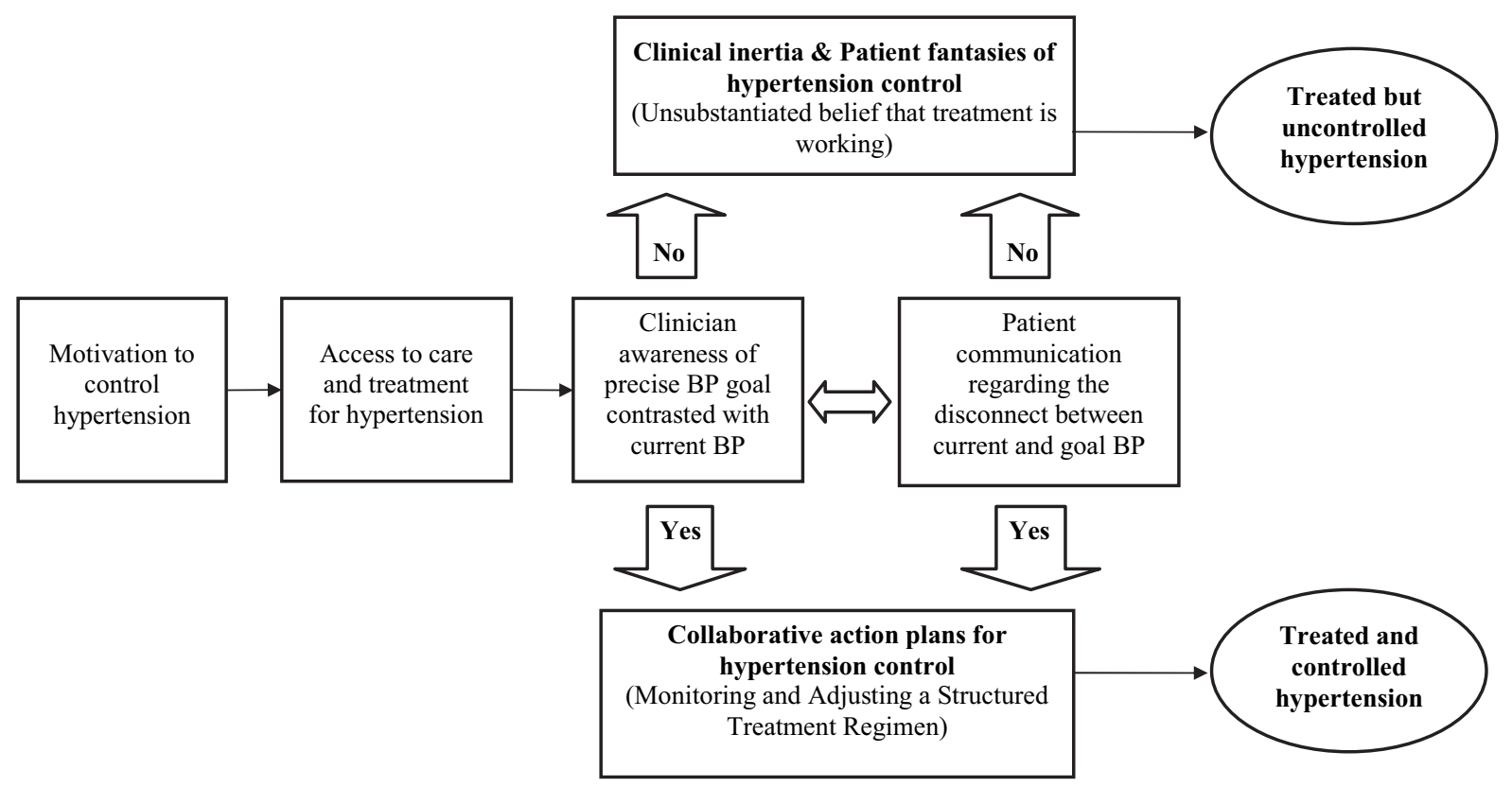

Figure 1. The role of collaborative goal setting and action planning to improve the effectiveness of treatment for hypertension control.

aware of their current status vis-à-vis their treatment goal are acting in accordance with cognitive "fantasies"48 (in contrast to goal-directed behaviors). Within this conceptual model, patients in a fantasy of hypertension control (see Figure 1) have strong intentions to seek care, are compliant with treatment, and report satisfaction with their clinicians, ${ }^{44,47}$ but are unaware of their specific blood pressure goal and current blood pressure measurement and play a passive role in monitoring and adjusting their treatments. ${ }^{48-50}$ Patients who are unaware of and not motivated by their uncontrolled status do not effectively collaborate with their physicians to address clinical inertia. ${ }^{4-51}$ Patients' cognitive fantasies, in conjunction with clinical inertia, may be an important determinant of treated but uncontrolled hypertension in routine diabetes care, despite adequate access and adherence to therapy. Further research is needed to verify this explanatory model.

The results of this review suggest that clinical trials of hypertension control avoid the cognitive errors associated with treated but uncontrolled hypertension (ie, clinical inertia and fantasies of control) by using co-maneuvers that facilitate collaborative goal setting and action planning (see Figure 1). ${ }^{52,53}$ These processes work by harnessing patient motivation and expectations into a cognitive schema that stresses self-awareness of current cir- cumstances, defining precisely framed collaborative goals and building self-efficacy to implement action plans for achieving collaborative goals. ${ }^{52-55}$ Every clinical trial that met the eligibility criteria for the current review used precise, predefined blood pressure targets (ie, goals), and most facilitated multiple opportunities (using frequent, early follow-up visits) for the patient and clinician to contrast current and goal blood pressures. Patient-clinician communication regarding the dissonance between goal and current blood pressure are essentially engrained into the structure of these trials through the use of monitoring and highly regimented treatment action plans. Fantasies of hypertension control are practically impossible among the trial participants because of the goal-setting paradigm underlying the co-maneuvers used in these clinical trials.

\section{Implications for Practice}

Clinicians who seek to improve the rates of hypertension control for their comorbid patients must do more than simply translate the principal interventions of clinical trials to routine diabetes care. Clinical trials embed cognitive and behavioral co-maneuvers into the patient-physician interaction to improve outcomes. These co-maneuvers are conceptually similar to collaborative goal-setting and action planning interventions, ${ }^{42-54}$ which have been used to reduce cardiovascular risk factors, ${ }^{55}$ 
enhance the self-management of diabetes, ${ }^{56,57}$ and improve planning for breast cancer treatment. ${ }^{58}$ Furthermore, clinicians' awareness of current versus goal blood pressure and patients' participation in treatment action planning may alleviate clinical inertia.

These processes can be integrated into the practices of busy clinicians caring for complex diabetic patients and applied to self-monitoring tasks and behavioral interventions as well as drug therapies. ${ }^{53,59}$ Contrary to expectations, goal setting can enhance the efficiency and effectiveness of hypertension control without disrupting the doctor-patient relationship; however, the initial integration may be difficult and will require a commitment of time and resources. ${ }^{51,52,59}$

\section{Limitations}

The findings of the current study must be weighed against several limitations. First, the quantitative effect of a principal maneuver was not considered when evaluating co-maneuvers of particular studies. In addition, because of the heterogeneity and small number of co-maneuvers among the included studies, a meta-analysis of their effectiveness could not be performed. Second, the assessment of comaneuvers relies on the methodologies reported by the study investigators and does not consider implementation factors that investigators may have used but did not publish. Third, there are no established criteria for assessing the use or quality of co-maneuvers in clinical trials. In response to this consideration, the current study used an established qualitative research methodology ${ }^{17}$ along with accepted standards for structured literature reviews to improve the rigor of the analyses. Finally, these analyses do not consider the impact of other important covariates to hypertension control, including social and demographic characteristics (eg, age and ethnicity), and important clinical differences between study populations.

\section{Conclusion}

Clinicians and investigators who seek to improve the rates of hypertension control for their patients with diabetes should do more than translate the principal interventions of clinical trials to routine diabetes care. Clinical trials also embed consensual expectations regarding monitoring and regulation of treatment to enhance the efficacy of the principal intervention. Patients with diabetes receiving chronic hypertension treatment have some important similarities with clinical trial participants. They are motivated to reduce their health risks, believe in the effectiveness of treatment, and generally adhere to the recommendations of their clinicians. Therefore, patients in routine diabetes care may benefit from the co-maneuvers used in clinical trials. Interventions using collaborative goal setting and action planning use three of these same core strategies: (1) define collaborative blood pressure goals, (2) measure and discuss blood pressure levels frequently, and (3) develop and implement an action plan for adjusting therapy when current blood pressure levels do not meet goals. Goal setting and action planning require commitment and an initial time investment, but the longitudinal benefits are improved quality and satisfaction with diabetes care.

The authors would like to thank Harlan M. Krumholz, MD, for his review of an earlier version of the manuscript; John Concato, $\mathrm{MD}$, for his comprehensive instruction regarding Feinstein's principles of clinical epidemiology; and Nelda P. Wray, MD, $\mathrm{MPH}$, and David Kuykendall, $\mathrm{PhD}$, for their valuable insights.

\section{References}

1. Haffner SM, Lehto S, Ronnemaa T, Pyorala K, Laakso M. Mortality from coronary heart disease in subjects with type 2 diabetes and in nondiabetic subjects with and without prior myocardial infarction. N Engl J Med 1998;339:229-34.

2. Sowers JR. Treatment of hypertension in patients with diabetes. Arch Intern Med 2004;164:1850-7.

3. Vijan S, Hayward RA. Treatment of hypertension in type 2 diabetes mellitus: blood pressure goals, choice of agents, and setting priorities in diabetes care. Ann Intern Med 2003;138:593-602.

4. UK Prospective Diabetes Study Group. Cost effectiveness analysis of improved blood pressure control in hypertensive patients with type 2 diabetes: UKPDS 40. BMJ 1998;317:720-6.

5. Chobanian AV, Bakris GL, Black HR, et al. The Seventh Report of the Joint National Committee on Prevention, Detection, Evaluation, and Treatment of High Blood Pressure: the JNC 7 report. JAMA 2003;289:2560-72.

6. Berlowitz DR, Ash AS, Hickey EC, Glickman M, Friedman R, Kader B. Hypertension management in patients with diabetes: the need for more aggressive therapy. Diabetes Care 2003;26:355-9.

7. Nilsson PM, Gudbjornsdottir S, Eliasson B, Cederholm J. Hypertension in diabetes: trends in clinical control in repeated large-scale national surveys from Sweden. J Hum Hypertens 2003;17:37-44. 
8. Kerr EA, Gerzoff RB, Krein SL, et al. Diabetes care quality in the Veterans Affairs Health Care System and commercial managed care: the TRIAD study. Ann Intern Med 2004;141:272-81.

9. Wang TJ, Vasan RS. Epidemiology of uncontrolled hypertension in the United States. Circulation 2005; 112:1651-62.

10. Hart PD, Bakris GL. Hypertension control rates: time for translation of guidelines into clinical practice. Am J Med 2004;117:62-4.

11. Haynes RB, McKibbon KA, Kanani R. Systematic review of randomised trials of interventions to assist patients to follow prescriptions for medications. Lancet 1996;348:383-6.

12. Hyman DJ, Pavlik VN. Self-reported hypertension treatment practices among primary care physicians: blood pressure thresholds, drug choices, and the role of guidelines and evidence-based medicine. Arch Intern Med 2000;160:2281-6.

13. Phillips LS, Branch WT, Cook CB, et al. Clinical inertia. Ann Intern Med 2001;135:825-34.

14. Fine LJ, Cutler JA. Hypertension and the treating physician: understanding and reducing therapeutic inertia. Hypertension 2006;47:319-20.

15. Institute of Medicine. Crossing the quality chasm: a new health system for the 21 st century. Washington, DC: National Academy Press, Institute of Medicine; 2001.

16. Feinstein AR. Clinical epidemiology: the architecture of clinical research. Philadelphia (PA): WB Saunders Co; 1985.

17. Crabtree BF, Miller WL. Doing qualitative research. 2nd ed. Thousand Oaks (CA): Sage Publications; 2000.

18. Curb JD, Pressel SL, Cutler JA, et al. Effect of diuretic-based antihypertensive treatment on cardiovascular disease risk in older diabetic patients with isolated systolic hypertension. Systolic Hypertension in the Elderly Program Cooperative Research Group. JAMA 1996;276:1886-92.

19. Tuomilehto J, Rastenyte D, Birkenhager WH, et al. Effects of calcium-channel blockade in older patients with diabetes and systolic hypertension. Systolic Hypertension in Europe Trial Investigators. N Engl J Med 1999;340:677-84.

20. Davis BR, Cutler JA, Gordon DJ, et al. Rationale and design for the Antihypertensive and Lipid Lowering Treatment to Prevent Heart Attack Trial (ALLHAT). Am J Hypertension 1996;9:342-60.

21. Whelton PK, Barzilay J, Cushman WC, et al. Clinical outcomes in antihypertensive treatment of type 2 diabetes, impaired fasting glucose concentration, and normoglycemia: Antihypertensive and Lipid-Lowering Treatment to Prevent Heart Attack Trial (ALLHAT). Arch Intern Med 2005;165:1401-9.

22. Niskanen L, Hedner T, Hansson L, Lanke J, Niklason A. Reduced cardiovascular morbidity and mortality in hypertensive diabetic patients on first-line therapy with an ACE inhibitor compared with a diuretic/beta-blocker-based treatment regimen: a subanalysis of the Captopril Prevention Project. Diabetes Care 2001;24:2091-6.

23. Lindholm LH, Ibsen H, Dahlof B, et al. Cardiovascular morbidity and mortality in patients with diabetes in the Losartan Intervention For Endpoint reduction in hypertension study (LIFE): a randomised trial against atenolol. Lancet 2002;359:1004-10.

24. Lindholm LH, Hansson L, Ekbom T, et al. Comparison of antihypertensive treatments in preventing cardiovascular events in elderly diabetic patients: results from the Swedish Trial in Old Patients with Hypertension-2. J Hypertens 2000;18:1671-5.

25. Mancia G, Brown M, Castaigne A, et al. Outcomes with nifedipine GITS or co-amilozide in hypertensive diabetics and nondiabetics in Intervention as a Goal in Hypertension (INSIGHT). Hypertension 2003;41:431-6.

26. Yui Y, Sumiyoshi T, Kodama K, et al. Nifedipine retard was as effective as angiotensin-converting enzyme inhibitors in preventing cardiac events in highrisk hypertensive patients with diabetes and coronary artery disease: the Japan Multicenter Investigation for Cardiovascular Diseases-B (JMIC-B) subgroup analysis. Hypertens Res Clinic Exp 2004;27:449-56.

27. Berl T, Hunsicker LG, Lewis JB, et al. Cardiovascular outcomes in the Irbesartan Diabetic Nephropathy Trial of patients with type 2 diabetes and overt nephropathy. Ann Intern Med 2003;138:542-9.

28. Black HR, Elliott WJ, Grandits G, et al. Principal results of the Controlled Onset Verapamil Investigation of Cardiovascular End Points (CONVINCE) trial. JAMA 2003;289:2073-82.

29. Bergamo Nephrologic Diabetes Complications Trial Investigators. Preventing microalbuminuria in type 2 diabetes. N Engl J Med 2004;351:1941-51.

30. Pepine CJ, Handberg-Thurmond E, Marks RG, et al. Rationale and design of the International Verapamil SR/Trandolapril Study (INVEST): an Internet-based randomized trial in coronary artery disease patients with hypertension. J Am Coll Cardiol 1998; 32:1228-37.

31. Tatti P, Pahor M, Byington RP, et al. Outcome results of the Fosinopril Versus Amlodipine Cardiovascular Events Randomized Trial (FACET) in patients with hypertension and NIDDM. Diabetes Care 1998;21:597-603.

32. The Nordic Diltiazem Study (NORDIL). A prospective intervention trial of calcium antagonist therapy in hypertension. Blood Press 1993;2:312-21.

33. Hypertension in Diabetes Study IV. Therapeutic requirements to maintain tight blood pressure control. Diabetologia 1996;39:1554-61.

34. UK Prospective Diabetes Study Group. Tight blood pressure control and risk of macrovascular and microvascular complications in type 2 diabetes: UKPDS 38. BMJ 1998;317:703-13. 
35. Hansson L, Zanchetti A, Carruthers SG, et al. Effects of intensive blood-pressure lowering and lowdose aspirin in patients with hypertension: principal results of the Hypertension Optimal Treatment (HOT) randomised trial. Lancet 1998;351:1755-62.

36. Estacio RO, Jeffers BW, Gifford N, Schrier RW. Effect of blood pressure control on diabetic microvascular complications in patients with hypertension and type 2 diabetes. Diabetes Care 2000;23(Suppl 2):B54-B64.

37. Gaede P, Vedel P, Larsen N, Jensen GV, Parving $\mathrm{HH}$, Pedersen O. Multifactorial intervention and cardiovascular disease in patients with type 2 diabetes. N Engl J Med 2003;348:383-93.

38. Rachmani R, Levi Z, Slavachevski I, Avin M, Ravid M. Teaching patients to monitor their risk factors retards the progression of vascular complications in high-risk patients with type 2 diabetes mellitus-a randomized prospective study. Diabet Med 2002;19: 385-92.

39. Culos-Reed SN, Rejeski WJ, McAuley E, Ockene JK, Roter DL. Predictors of adherence to behavior change interventions in the elderly. Control Clin Trials 2000;21(5 Suppl):200S-205S.

40. Robiner WN. Enhancing adherence in clinical research. Contemp Clin Trials 2005;26:59-77.

41. MaDonald HP, Garg AX, Haynes RB. Interventions to enhance patient adherence to medication prescriptions: scientific review. JAMA 2003;288:286879.

42. Renders CM, Valk GD, Griffin SJ, Wagner EH, Eijk Van JT, Assendelft WJ. Interventions to improve the management of diabetes in primary care, outpatient, and community settings: a systematic review. Diabetes Care. 2001;24:1821-33.

43. Boulware LE, Daumit GL, Frick KD, Minkovitz CS, Lawrence RS, Powe NR. An evidence-based review of patient-centered behavioral interventions for hypertension. Am J Prev Med 2001;21:221-32.

44. Hyman DJ, Pavlik VN. Characteristics of patients with uncontrolled hypertension in the United States. N Engl J Med 2001;345:479-86.

45. Kravitz RL, Bell RA, Azari R, Krupat E, Kelly-Reif $\mathrm{S}$, Thom D. Request fulfillment in office practice: antecedents and relationship to outcomes. Med Care 2002;40:38-51.

46. Greenfield S, Kaplan SH, Ware JE Jr, Yano EM, Frank HJ. Patients' participation in medical care: effects on blood sugar control and quality of life in diabetes. J Gen Intern Med 1988;3:448-57.
47. Oliveria SA, Chen RS, McCarthy BD, Davis CC, Hill MN. Hypertension knowledge, awareness, and attitudes in a hypertensive population. J Gen Intern Med 2005;20:219-25.

48. Oettingen G, Mayer D. The motivating function of thinking about the future: expectations versus fantasies. J Pers Soc Psychol 2002;83:1198-212.

49. Oettingen G, Pak H, Schnetter K. Self-regulation of goal setting: turning free fantasies about the future into binding goals. J Pers Soc Psychol. 2001;80: 736-53.

50. Heisler M, Vijan S, Anderson RM, Ubel PA, Bernstein SJ, Hofer TP. When do patients and their physicians agree on diabetes treatment goals and strategies, and what difference does it make? J Gen Intern Med 2003;18:893-902.

51. Von Korff M, Glasgow RE, Sharpe M. Organising care for chronic illness. BMJ 2002;325:92-4.

52. Lorig K. Action planning: a call to action. J Am Board Fam Med. 2006;19:324-5.

53. Locke EA, Latham GP. Building a practically useful theory of goal setting and task motivation. A 35-year odyssey. Am Psychol 2002;57:705-17.

54. Naik AD, Schulman-Green D, McCorkle R, Bradley EH, Bogardus ST. Will older persons and their clinicians use a shared decision making instrument? J Gen Intern Med 2005;20:640-3.

55. Handley M, MacGregor K, Schillinger D, Sharifi C, Wong S, Bodenheimer T. Using action plans to help primary care patients adopt healthy behaviors: a descriptive study. J Am Board Fam Med 2006;19:22431.

56. Estabrooks PA, Nelson CC, Xu S, et al. The frequency and behavioral outcomes of goal choices in the self-management of diabetes. Diabetes Educ 2005;31:391-400.

57. Funnell MM, Nwankwo R, Gillard ML, Anderson RM, Tang TS. Implementing an empowermentbased diabetes self-management education program. Diabetes Educ 2005;31:53, 55-6, 61.

58. Mandelblatt J, Kreling B, Figeuriedo M, Feng S. What is the impact of shared decision making on treatment and outcomes for older women with breast cancer? J Clin Oncol 2006;24:4908-13. Epub 2006 Sept 18.

59. MacGregor K, Handley M, Wong S, et al. Behaviorchange action plans in primary care: a feasibility study of clinicians. J Am Board Fam Med 2006;19: 215-23. 